TARNOWSKIE STUDIA TEOLOGICZNE 35 (2016) NR 2, s. 73-89

http://dx.doi.org/10.15633/tst.2106

Marcin Imach ${ }^{1}$

UNIWERSYTET ŚLĄSKI

\title{
Kościół w Armenii - podziały i dążenie do jedności
}

Coraz częstsze wspominanie w mediach o eksterminacji Ormian przez Turków, która dokonała się na początku xx wieku, doprowadziło do sytuacji, że wielu ludzi zaczęło postrzegać ten naród jako chrześcijański. Nietrudno domyślić się, że wierni geograficznie oddaleni od Rzymu zapewne posiadali odrębny obrządek, jak i własną tradycję.

Wydaje się zatem, że krótkie przedstawienie losów oraz obecnej sytuacji ormiańskich chrześcijan jest czymś aktualnym i może zainteresować czytelnika. Trzeba zaznaczyć, że nie brak publikacji dotyczących historii Kościoła ormiańskiego w języku polskim, które kompleksowo ujmują problematykę. Ważny wydaje się wątek wewnętrznych podziałów wśród wyznawców oraz ich łączność z Rzymem i dlatego w niniejszego artykule zostaną zarysowane historyczne i współczesne uwarunkowania sytuacji tego Kościoła, podkreślające skutki podziałów i podjęte działania o charakterze ekumenicznym.

$\mathrm{Na}$ początek zostanie przedstawiona krótko historia Kościoła ormiańskiego na tle historii samej Armenii. Następnie zostaną wskazane podziały w ramach Apostolskiego Kościoła Ormiańskiego, jakie dokonały się na przestrzeni wieków. Posłuży to jako tło do ukazania rozdziału pomiędzy Apostolskim Kościołem Ormiańskim a ormiańskim Kościołem katolickim, dokonującego się na przestrzeni wieków. Ze względu na zainteresowanie społeczne chrześcijanami ormiańskimi przy okazji setnej rocznicy ich eksterminacji, zostanie ona ukazany jako element, który w obecnych czasach może integrować Ormian, niezależnie od ich przynależności kościelnej. Jest to niewątpliwie ważny punkt współczesnych działań ekumenicznych,

1 Marcin Imach - absolwent Katolickiego Uniwersytetu Lubelskiego (Wydział Teologiczny) oraz Śląskiej Wyższej Szkoły Zarządzania. Doktorant na Wydziale Teologicznym Uniwersytetu Śląskiego w Katowicach. Członek Stowarzyszenia Misjologów Polskich. 
które pokazują możliwość powrotu Apostolskiego Kościoła Ormiańskiego do jedności z Rzymem.

\section{Historia Kościoła ormiańskiego}

Chcąc zajmować się zagadnieniem Kościoła ormiańskiego, warto zauważyć, że historycznie Armenia to wyżyna między Kaukazem, Azją Mniejszą a Persją. Pod koniec IV wieku przed Chrystusem na tym terenie upadało państwo Urartu, i to z tym faktem przeważnie wiąże się początek kształtowania narodu ormiańskiego ${ }^{2}$. W zasadzie obecne granice tego górzystego kraju zostały ustalone w roku 1920.

Według legendy Ormianie są potomkami Noego. Jako pierwsi zaludnili okolice góry Ararat, a w roku 93 przed Chrystusem Togranes I Wielki stworzył tam pierwsze znaczące państwo ormiańskie. O teren ten toczyły się przeważnie zacięte boje pomiędzy Rzymem a Persją ${ }^{3}$.

Jeśli chodzi o chrześcijaństwo na ziemiach Armenii, to pierwsze pewne ślady jego obecności pochodzą z końca II wieku po Chrystusie. Naukę Chrystusa mieli tam zanieść Tadeusz, będący syryjskim uczniem wysłanym do Edessy, oraz Bartłomiej Apostoł ${ }^{4}$. Informacje o tym, iż Ewangelię na tych terenach głosili właśnie apostołowie Bartłomiej oraz Juda Tadeusz zawarte są w bardzo wielu źródłach ${ }^{5}$. Ormiańscy historycy przyznają jednak, że wielkim impulsem dla rozwoju chrześcijaństwa w Armenii była działalność Grzegorza Oświeciciela ${ }^{6}$. Był on z pochodzenia Partem, jednak w Cezarei Kapadockiej zapoznał się z chrześcijaństwem. Miał mianować osobiście około 400 biskupów $^{7}$. Dlatego powszechnie uznaje się, że już w III wieku za sprawą Grzegorza Oświeciciela Ormianie zostali doprowadzeni do chrześcijaństwa ${ }^{8}$.

Zob. G. Kucharczyk, Pierwszy holokaust xx wieku, Warszawa 20014, s. 13-15.

Zob. H. Gstrein, Skazany na chłostę i śmierć, przeł. J. Borowiczowa, Warszawa 1991, s. 9.

4 Zob. P. Siniscalco, Starożytne Kościoły wschodnie, przeł. K. Piekarz, Kraków 2013, s. 234-236.

5 http://ekumenizm.wiara.pl/doc/477865.Ormianski-Kosciol-Apostolski-Kosciol-OrmianskoGregorianski (13.05.2015).

6 Zob. P. Siniscalco, Starożytne Kościoły..., s. 234-236.

7 http://ekumenizm.wiara.pl/doc/477865.Ormianski-Kosciol-Apostolski-Kosciol-OrmianskoGregorianski (13.05.2015).

8 Zob. H. Gstrein, Skazany na..., s. 9. 
Według przekazów historycznych już w roku 252 w Erywaniu przed królem Armenii miała miejsce dysputa pomiędzy chrześcijanami a przedstawicielami manicheizmu. Wówczas to jedni i drudzy zachęcali do przyjęcia przez ten kraj reprezentowanej przez siebie religii. Ale to chrześcijaństwo już pod koniec III wieku po Chrystusie mocno zapuściło korzenie w Armenii. Ważnym ośrodkiem chrześcijańskim był wówczas Asztiszat, gdzie został wzniesiony pierwszy kościół, nazwany później matką wszystkich kościołów Armenii.

Równolegle, pod koniec III wieku po Chrystusie, Królestwo Armenii politycznie przeszło pod protektorat Rzymu. To właśnie Rzymianie mianowali królem Titydatesa III, który wychowywał się na dworze cesarskim ${ }^{9}$ i z którym w dużej mierze wiąże się przełomowe dla Ormian wydarzenie religijne $\mathrm{z}$ roku 301. Wówczas to władca Armenii, właśnie wspomniany Tirydates III $^{10}$, przyjął oficjalnie chrześcijaństwo. Dzięki temu Armenia stała się pierwszym w historii krajem chrześcijańskim ${ }^{11}$. Należy zauważyć, że nastąpiło to jeszcze przed wstąpieniem na cesarski tron Konstantyna Wielkiego, który nieco później ustanowił chrześcijaństwo religią państwową ${ }^{12}$.

Rozpoczął się dzięki temu okres dynamicznego rozwoju kultury Ormian. Równocześnie widoczne już były wpływy chrześcijaństwa na prawie cały Kaukaz, który w IV-V wieku po Chrystusie zapoznał się z chrześcijaństwem $^{13}$. Choć utrudnieniem dla działań Kościoła był fakt, że pod koniec IV wieku kraj został podzielony pomiędzy Bizancjum a Persję ${ }^{14}$. W Armenii chrześcijaństwo stało się tak znaczące, iż przejmowano majątki pogańskich świątyń, które były burzone. Natomiast popularność samego Grzegorza Oświeciciela była na tyle wielka, że doprowadziło to do sytuacji, w której nastąpiło dziedziczenie patriarchatu ${ }^{15}$. Oczywiście można zapytać, czy już sam fakt, iż osoba świętego odcisnęła tak znaczące piętno na chrześcijanach

9 Zob. K. Stopka, Armenia Christiana, Kraków 2002, s. 20-23.

${ }^{10}$ Zob. Nazwa tego króla w różnych źródłach bywa nieco odmiennie przedstawiana - przeważnie Tirydates.

${ }^{11}$ Zob. G. Kucharczyk, Pierwszy holokaust..., s. 13-15.

${ }_{12}$ Zob. H. Gstrein, Skazany na..., s. 9.

${ }_{13}$ Zob. A. Curanowić, Religie, Kościoły i konflikty międzywyznaniowe w regionie Kaukazu, w: Wprowadzenie do studiów wschodnioeuropejskich, red. M. Korzeniowski, D. Tarasiuk, K. Latawiec, Lublin 2013, s. 189.

${ }^{14}$ Zob. G. Kucharczyk, Pierwszy holokaust..., s. 13-15.

${ }_{15}$ Zob. http://ekumenizm.wiara.pl/doc/477865.Ormianski-Kosciol-Apostolski-Kosciol-OrmianskoGregorianski (13.05.2015). 
ormiańskich, nie wpłynął na ich późniejszy separatyzm, stanowiący o utracie jedności z Rzymem. Z drugiej jednak strony można byłoby np. podać przykład św. Marona, który nieco podobną rolę odegrał u maronitów. Oni jednak pozostali w jedności ze Stolicą Apostolską.

Przez stosunkowo krótki okres, aż do ustanowienia przez Konstantyna Wielkiego chrześcijaństwa równoprawną religią, chrześcijanie w Armenii nie mogli czuć się bezpiecznie. Potwierdza to fakt, iż w latach 311/312 Rzymianie zorganizowali niejako karną ekspedycję do Armenii, aby nakłonić swoich przyjaciół i sprzymierzeńców do uznawania kultu bożków rzymskich ${ }^{16}$. Być może to konfliktowe wydarzenie zrodziło wrogość do Cesarstwa i stało się podstawą późniejszych problemów z utrzymaniem przez Ormian jedności z Rzymem.

Lepszemu poznaniu wiary przez Ormian przysłużyło się to, że św. Mesrob, będący mnichem, około roku 460 ustalił alfabet ormiański, co umożliwiło przetłumaczenie Biblii na ich język ${ }^{17}$. Dzięki temu poza środowiskiem greckim, łacińskim i syryjskim, które miały dostęp do tłumaczeń Biblii, także Ormianie mogli poznać Pismo święte we własnym języku ${ }^{18} . \mathrm{Z}$ drugiej strony trzeba zauważyć, że tłumaczenie sprawiło, iż pojawiały się różnice w brzmieniu nie tylko imion biblijnych, ale także opowiadań biblijnych oraz dokumentów kościelnych, co z pewnością nie sprzyjało utrwalaniu jedności kościelnej, ze względu na błędnie rozumienie pewnych stwierdzeń. Jak się później okazało, wynikało to tylko i wyłącznie z błędów popełnionych przy tłumaczeniu.

Rozwój chrześcijaństwa w Armenii był jednak nadal tak duży, że udało się w IV wieku wprowadzić regulacje kościelne dotyczące małżeństwa, które dotychczas opierało się na prawie państwowym oraz dokonać wprowadzenia specjalnego podatku na budowę przytułków oraz szpitali ${ }^{19}$. Wypracowywano w ten sposób pewną odrębność Kościoła Ormian, który we własnym zakresie próbował rozwiązywać niektóre problemy.

${ }^{16}$ Zob. K. Stopka, Armenia Christiana..., s. 25 n.

${ }_{17}$ Nie brak też teorii dotyczących tego, że twórcą alfabetu był Mesropow Masztocow żyjący na przełomie IV i v wieku, który może być traktowany jako osoba tożsama z przedstawionym mnichem. Zob. R. Roberson, Chrześcijańskie Kościoły wschodnie, przeł. K. Bielawski, D. Mionskowska, Bydgoszcz 1998, s. 34.

${ }_{18}$ Zob. P. Siniscalco, Starożytne Kościoły..., s. 239.

19 Zob. http://ekumenizm.wiara.pl/doc/477865.Ormianski-Kosciol-Apostolski-Kosciol-OrmianskoGregorianski (13.05.2015). 
Równocześnie nie można nie pamiętać o tym, że Ormianie odgrywali ogromną rolę w Cesarstwie Bizantyjskim. Przykładem może być dowódca wojsk bizantyjskich Wahan, który przed decydującą bitwą z Arabami nad rzeką Jarmuk w 636 roku mógł zostać obwołany cesarzem. Przeszkodziła temu tylko ogromna klęska wojsk bizantyjskich, a sam Wahan w tej sytuacji został mnichem na Synaju ${ }^{20}$. Wydarzenie to przyczyniło się zapewne do tego, że w latach 640-650 ziemie Armenii podbili Arabowie. Był to bez wątpienia czynnik utrudniający kontakty Ormian z Kościołem powszechnym, którego wyznacznikiem był Rzym² ${ }^{21}$ Muzułmanie, którzy byli początkowo uważani za chrześcijańskich heretyków, opanowali militarnie chrześcijańskich Ormian $^{22}$. We władaniu Bizancjum pozostała tylko tzw. Mała Armenia położona na południowo-wschodnim wybrzeżu Morza Czarnego. Pod koniec IX wieku za sprawą oderwania części ziem od kalifatu w Bagdadzie udało się tam stworzyć odrębne królestwo Armenii, które jednak w roku 1045 upadło. Rozpoczął się wówczas wielki ruch migracyjny wśród Ormian, co przyczyniało się do powstawania, a następnie utrwalania pewnej różnorodności w ramach chrześcijaństwa ormiańskiego.

Do kolejnej fali migracji Ormian doszło za sprawą najazdu Mongołów w XIII oraz Turków w XIV wieku. Osiedlili się wówczas na północnym wybrzeżu Morza Czarnego. Z kolei pod panowaniem Turków osmańskich ich los nie był zbyt dobry. Podobnie jak inni chrześcijanie, traktowani byli jako obywatele drugiej kategorii. Jedynie przyjęcie islamu mogło dać im szansę zyskania awansu społecznego i zdobycia np. posady urzędnika ${ }^{23}$.

\section{Podziały o charakterze religijnym wśród Ormian}

Jeżeli przyjąć, że pierwsze wieki chrześcijaństwa w Armenii, a w zasadzie do połowy v wieku, charakteryzowało szybkie rozprzestrzenianie się Kościoła, pozostającego w łączności z Kościołem powszechnym, to kolejny okres oznaczał już liczne zawirowania, które należy krótko scharakteryzować.

Już w początkach chrześcijaństwa w Armenii, na skutek wojny pomiędzy Rzymem a Persją, Ormian nie było na soborze w Chalcedonie w 451 roku.

\footnotetext{
${ }^{20}$ Zob. K. Nitkiewicz, Katolickie Kościoły wschodnie, Sandomierz 2014, s. 168.

${ }^{21}$ Równocześnie Ormianie byli już wówczas traktowani jako heretycy monofizyccy.

${ }_{22}$ Zob. D. Rudnicka-Kassem, John Paul II, Islam and the Middle East, Kraków 2012, s. 25n.

${ }^{23}$ Zob. G. Kucharczyk, Pierwszy holokaust..., s. 13-17.
} 
Być może miało to jakiś wpływ na fakt, że na Synodzie w Dwinie w vi wieku Ormianie odrzucili postanowienia $\mathrm{z}$ Chalcedonu. Jednakże dopiero pod koniec wieku viıI w tym Kościele zaczęły silnie przeważać tendencje antychalcedońskie ${ }^{24}$. Należy także pamiętać o względach narodowościowych, które miały ogromne znaczenie, szczególnie w wiekach od v do vir. Można wręcz przypuszczać, że przyjęty monofizytyzm, czy też odrzucenie uchwał chalcedońskich, były związane z pewną opozycją wobec Cesarstwa, które niejako okupowało Armenię 25 .

Z kolei nieco wcześniej uniezależnienie się Ormian od Kościoła w Cezarei doprowadziło do sytuacji, w której ten drugi często domagał się uznania swej zwierzchności i próbował podważyć ortodoksję Ormian. Zarzucano im wówczas używanie w liturgii chleba niekwaszonego, pomimo tego, że było to zgodne z tradycją żydowskiej Paschy oraz zwyczajem Kościoła łacińskiego. Równocześnie dopatrywano się herezji monofizytyzmu w tym, iż podczas Eucharystii nie mieszano wina i wody. Po soborze w Chalcedonie zwyczaj ten został jednak uznany jako wiara w prawdziwe bóstwo i człowieczeństwo Jezusa ${ }^{26}$.

W 642 roku muzułmańscy Arabowie zdobyli Dwin. Ormianie zaczęli odtąd podlegać kalifowi. Równocześnie będąc wyznawcami monofizytyzmu, znacząco oddalili się od Konstantynopola. Początkowe tolerowanie chrześcijańskich Ormian przez muzułmanów zamieniło się w x wieku za czasów dynastii Abbasydów na prześladowania. Istniejące jeszcze w tym czasie ormiańskie królestwo Bagratydów zostało w roku 1045 zlikwidowane przez Konstantynopol. Bez wątpienia to, że część Ormian podlegała pod kalifa, część pod Bizancjum, a jeszcze inna część utrzymywała niezależność, sprzyjało podziałom w ramach Kościoła ormiańskiego, niepozostającego już wówczas w jedności z Rzymem.

W xi wieku wielu książąt ormiańskich pozostawiło swoje tereny, które były zajęte częściowo przez Bizancjum, Mongołów, Persów, Seldżuków, i przeniosło się do Cylicji. Książę ormiański o imieniu Ruben otrzymał w lenno cylicyjskie miasto Lampron. Następnie jego następca Konstantyn I nawiązał

${ }^{24}$ Zob. P. Siniscalco, Starożytne Kościoły..., s. 240.

${ }_{25}$ Zob. M. Simon, Cywilizacja wczesnego chrześcijaństwa, przeł. E. Bakowska, Warszawa 1979, s. 358 .

${ }^{26}$ Zob. http://ekumenizm.wiara.pl/doc/477865.Ormianski-Kosciol-Apostolski-Kosciol-OrmianskoGregorianski (13.05.2015). 
kontakty z krzyżowcami. Z kolei w 1199 roku zostało założone ormiańskie królestwo Cylicji, zwane też Małą Armenią. Jego byt nie był jednak spokojny. Nękali go Mongołowie oraz egipscy mamelucy. Istnienie tego królestwa dało jednak zaczątki ormiańskim katolikom, choć nieuznawanie papieża za swojego zwierzchnika przez wszystkich Ormian spowodowało w konsekwencji dalsze podziały.

Problemy Ormian w Cylicji doprowadziły do sytuacji, w której w 1441 roku siedziba najwyższego katolikosa, znajdująca się w Sis w Cylicji, została przeniesiona do Eczmiadzyna. Praktycznie do dziś oprócz tego ośrodka istnieją jeszcze inne, w których rezydują katolikosi niższej rangi, tj. Sis i Ahtamar. Z kolei w Konstantynopolu i Jerozolimie znajdują się patriarchowie bez tytułu katolikosa ${ }^{27}$. Jest to już bez wątpienia jeden z podziałów występujących w ramach Apostolskiego Kościoła Ormiańskiego. Warto w tym miejscu zaznaczyć, że przedstawiony podział nie był wyłącznie związany z podziałem terytorialnym. Często bowiem zdarzało się, że ośrodki te nie zgadzały się w istotnych kwestiach dotyczących Apostolskiego Kościoła Ormiańskiego.

W roku $1461 \mathrm{w}$ Stambule na mocy decyzji sułtana Mehmeda II utworzono patriarchat ormiański. Patriarcha w tym przypadku był nie tylko głową Kościoła, ale także pewnego rodzaju zwierzchnikiem samorządu ormiańskiego $^{28}$. Istotne jednak było to, że ów patriarcha w sprawach cywilnych reprezentował wszystkich Ormian, tych pozostających w jedności z papieżem, jak i tych z niezależnego patriarchatu. Można powiedzieć, iż podział tego Kościoła nie polega tylko i wyłącznie na braku uznawania zwierzchnictwa papieża, czy na różnicy w poglądach religijnych. Istnieje także różnica w celebracjach liturgicznych w ramach Apostolskiego Kościoła Ormiańskiego, który nazywany jest także gregoriańskim ze względu na to, iż pierwszym patriarchą i katolikosem, był wspomniany wyżej Grzegorz Oświeciciel ${ }^{29}$. Różnica ta wynika ze stosowania dwóch rytów: libańskiego lub lwowskiego, które są w użyciu po dzień dzisiejszy. Oczywiście w rycie lwowskim widoczne są wpływy liturgii grecko-katolickiej. W związku z tym kapłani ormiańscy, którzy wywodzący się z Europy wschodniej, są zobowiązani do noszenia brody, a podczas celebracji liturgicznej stoją tyłem do wiernych. Modlitwy wypowiadają w języku staroormiańskim, a sama celebracja

${ }^{27}$ Zob. P. Siniscalco, Starożytne Kościoły..., s. 241-243.

${ }_{28}$ Zob. G. Kucharczyk, Pierwszy holokaust..., s. 2 on.

${ }^{29}$ Zob. K. Nitkiewicz, Katolickie Kościoły..., s. 104. 
mszy świętej może trwać nawet do 1,5 godziny ze względu na obligatoryjny i dominujący śpiew chóru. W rycie tym, sam obrzęd przygotowania darów został włączony do mszy świętej, bezpośrednio przed anaforą, w której stosuje się również opis ustanowienia eucharystii z Ostatniej Wieczerzy, uznawany przez Kościół łaciński za moment przeistoczenia i konsekracji. Ponadto w rycie tym wprowadzono odmawianie modlitwy Ojcze nasz. Są to elementy (poza śpiewem chóru), których nie stosuje się w rycie libańskim, gdyż zachował on swoją pierwotną i bardziej starożytną formę. To, co od razu rzuca się w oczy osobie, która obserwuje taką celebrację, to ubiór kapłana do mszy świętej. Zakłada on długie szaty liturgiczne, a zamiast butów ozdobne pantofle, natomiast na głowę wkłada tzw. koronę kapłańską. Istnieje oczywiście wiele innych różnic, których nie trzeba tutaj przywoływać, gdyż celem artykułu nie jest opisywanie liturgii ormiańskiej ${ }^{30}$.

\section{Początki ormiańskiego Kościoła katolickiego}

Jak już wspomniano, Ormianie nie zaakceptowali uchwał Soboru w Chalcedonie z roku 451. Do pewnego zjednoczenia z Rzymem doszło w ramach powstałego wspomnianego królestwa w Cylicji. Jednak większość Ormian tego nie zaakceptowała. Dlatego też droga do łączności ze Stolicą Apostolską nie była krótka i prosta.

Uznaje się, że już w xıI wieku krzyżowcy nawiązali bliskie kontakty ze wspólnotą Ormian, a w roku 1198 doszło do unii, której jednak nie zaakceptowali Ormianie mieszkający poza Cylicją $a^{31}$. Jednak dopiero na początku XIV wieku Kościół ormiański w Cylicji wprowadził w życie wiele reform, od których Rzym uzależniał przyznanie korony dla dynastii książąt ormiańskich. Dlatego należy uznać, że wzajemne relacje pomiędzy Rzymem a Ormianami w XIII wieku miały charakter bardziej dyplomatyczny niż religijny.

W zasadzie to synody unijne doprowadziły do tego, że Kościół ormiański w Cylicji przystąpił do wdrażania reform związanych ze zmianami w obrządku. Trzeba w tym miejscu zaznaczyć, że Rzym traktował Ormian całkowicie na równi z łacinnikami. Papieże Klemens v i Jan xxı nadawali odpusty Kościołom ormiańskim św. Sergiusza w Sis, Najświętszej Marii Panny w Famaguście na Cyprze, św. Bartłomieja w Genui oraz innym. W 1312 roku papież

${ }^{30}$ Zob. http://www.magazyn.ekumenizm.pl/content/article/20040705134933238.htm (18.05.2015).

${ }^{31}$ Zob. R. Roberson, Chrześcijańskie Kościoły..., s. 153-156. 
Klemens v skarcił inkwizytora, który wychodząc z założenia, że różnorodność w obrządku prowadzi do różnorodności w wierze, aresztował księdza ormiańskiego Leonarda, syna Stefana, i skonfiskował majątek kościelny. Interesujące jest na pewno to, że zdecydowanie najchętniej przyjmowali zbliżenie pomiędzy Kościołami władza królewska oraz baronowie. W 1321 roku papież Jan XxII zezwolił katolikosowi Konstantynowi III na udzielenie w swym imieniu dyspensy od przeszkody małżeńskiej nowemu królowi Leonowi Iv. Warto też nadmienić, że w tym czasie w Królestwie Armenii obok biskupstw ormiańskich funkcjonowały dwa arcybiskupstwa oraz dwa biskupstwa łacińskie. Wszystko to służyło wzajemnemu zbliżeniu ${ }^{32}$.

Natomiast na soborze florenckim w 1439 roku został opublikowany dekret o ponownym zjednoczeniu Apostolskiego Kościoła Ormiańskiego z Rzymem. Często twierdzi się, że to właśnie on stanowił podstawę do utworzenia w późniejszym czasie ormiańskiego Kościoła katolickiego, znanego aż do czasów nam współczesnych ${ }^{33}$. Trzeba jednak pamiętać, że sobór ten odbywał się w czasie, gdy Turcy osmańscy zagrażali Konstantynopolowi ${ }^{34}$. Na pewno nie pozostało to bez znaczenia dla podejmowanych przez Ormian decyzji, które prawdopodobnie nie do końca były wolne i wynikające z głębokiego przekonania, a jedynie oparte na ludzkiej kalkulacji.

Ważnym etapem na drodze do jedności z Rzymem był dla Ormian rok 1635, kiedy to biskup eparchii lwowskiej złożył przed papieżem wyznanie wiary, przywracając częściowo jedność z Rzymem³ ${ }^{35}$. Choć z drugiej strony przyczyniło się to do dalszych podziałów wśród chrześcijańskich Ormian. Ale dopiero w roku 1742 papież Benedykt xıv mianował Abrahama Ardziwiana patriarchą Ormian Cylicji i nadał mu także władzę religijną nad ormiańskimi katolikami na południowych terenach Imperium Otomańskiego.

Warto wspomnieć także o pewnym problemie, który dotyczył w tych czasach katolików ormiańskich. Otóż system tureckiej jurysdykcji związany z systemem miletó ${ }^{36}$ doprowadził do sytuacji, w której ormiańscy katolicy

${ }^{32}$ Zob. K. Stopka, Armenia Christiana..., s. 179-19o.

${ }_{33}$ Zob. R. Roberson, Chrześcijańskie Kościoły..., s. 153-156.

${ }^{34}$ Zob. K. Bukowski, Religie świata wobec chrześcijaństwa, Kraków 1999, s. 206.

35 Zob. http://www.magazyn.ekumenizm.pl/content/article/20040705134933238.htm (18.05.2015).

${ }^{36}$ System miletów był związany z autonomią poszczególnych religii w ramach państwa ottomańskiego - dotyczyło to także poszczególnych wyznań chrześcijańskich. Przywódca duchowy danej grupy religijnej był równocześnie przywódcą duchowym. Odpowiadał przeważnie bezpośrednio przez sułtanem. 
podlegali Ormiańskiemu Patriarchatowi Apostolskiemu w Konstantynopolu. Nie dawało to niestety wystarczającego zabezpieczenia przed muzułmańskimi prześladowaniami. Trzeba wręcz przyznać, że raczej je wzmogło i przedłużyło aż do 1829 roku, kiedy to pod naporem Francji Turcja zgodziła się na oddzielny milet dla Ormian katolickich. W 1928 roku zdecydowano, by patriarchat katolickich Ormian znajdował się ponownie w Bejrucie (Liban).

Obecnie wielu ormiańskich katolików znajduje się w Libanie oraz Syrii. Liczbę wiernych szacuje się na około 249 tysięcy $^{37}$, choć są dane mówiące o 550 tysiącach, a nawet o 600 tysiącach wiernych ${ }^{38}$. Kościół katolicki obrządku ormiańskiego (uznający zwierzchnictwo papieża) od wielu wieków istniał $\mathrm{w}$ ramach społeczeństwa ormiańskiego, stanowiąc jednak zawsze znaczną mniejszość w stosunku do Apostolskiego Kościoła Ormiańskiego. Był niejako pewną częścią planu, który miał na celu doprowadzenie do jedności wszystkich Ormian z Rzymem. Obecnie funkcjonowanie i struktura ormiańskiego Kościoła katolickiego są regulowane kodeksem kanonów Kościołów wschodnich ${ }^{39}$.

\section{Eksterminacja Ormian}

Jeśli chodzi o prześladowania, to dotyczyły one wszystkich Ormian, niezależnie od panujących wśród nich podziałów na tych katolickich lub apostolskich $^{40}$. Jednak tym, co obecnie szczególnie jednoczy Ormian, jest wspólna pamięć o prześladowaniach dokonanych na początku xx wieku.

Już na wstępie należy zaznaczyć, że w okresie I wojny światowej przywódcy młodotureccy byli zafascynowani Niemcami. Enver Pasza zamierzał wręcz doprowadzić do osiedlenia Niemców w Anatolii, zapewne w miejscu, z którego zamierzano wysiedlić Ormian. Plany wysiedlenia Ormian powstały także w Niemczech ${ }^{41}$. Zamierzano ich przesiedlić na tereny wzdłuż powstającej magistrali kolejowej Berlin-Bagdad. Uważano wówczas, że ludność ormiańska, znana z przedsiębiorczości, znakomicie będzie się nadawała

37 Zob. R. Roberson, Chrześcijańskie Kościoły..., s. 153-156.

${ }^{8}$ Zob. http://www.ordynariat.ormianie.pl/(6.01.2015).

${ }^{39} \mathrm{http} / / /$ www.magazyn.ekumenizm.pl/content/article/20040705134933238.htm (18.05.2015).

${ }^{40}$ Można tu na pewno wymienić pewne wyjątki, jak np. w czasach imperium osmańskiego, gdy katoliccy Ormianie nie posiadali jeszcze własnego miletu.

${ }_{41}$ Warto przypomnieć, że podczas I wojny światowej Turcja była sprzymierzona z Niemcami. 
do zamieszkiwania tego terenu. Można zatem stwierdzić, że była to pewna forma komplementowania Ormian, aby ich zachęcić do dobrowolnej migracji. To właśnie podczas owych przesiedleń, związanych z długimi marszami ludności ormiańskiej w bardzo złych warunkach, dochodziło często do śmierci wielu wśród nich. W sensie religijnym traktowano Ormian jako chrześcijan, nie wnikając w ich wewnętrzne podziały, choć oczywiście można uznać, że w pewnym sensie bezpieczniej mogli się czuć ormiańscy katolicy, którzy liczyli na pomoc ze strony Francji.

Na początku 1915 roku Behhaedin Sakir, będący wówczas wpływową postacią w tureckim życiu politycznym, oświadczył, że konieczne jest, aby od Stambułu po Indie i Chiny istniała ludność jednolita pod względem wyznaniowym, a mianowicie muzułmanie. Sądzono, że w realizacji tego planu mieli pomóc Niemcy ${ }^{42}$. W związku z takim nastawieniem nie miało znaczenia, czy dany Ormianin należał do Kościoła katolickiego czy apostolskiego.

Pewną symboliczną datą ludobójstwa Ormian jest 24 kwietnia, kiedy to w 1915 roku tajna policja turecka aresztowała w Stambule tysiące intelektualistów ormiańskich. W rzeczywistości jest to data rozpoczęcia eksterminacji Ormian trwającej dwa lata, choć pierwsze próby masakry miały miejsce już pod koniec XIX wieku. Władze tureckie chciały wyprzeć ze zdobytego terytorium zarówno Ormian, jak i Greków, osiedlając w to miejsce Turków i Kurdów. Celem nadrzędnym było pozbycie się wszystkich wyznawców religii innej niż islam i odbudowanie potęgi Imperium Otomańskiego. W latach 1915-1916 trwało ludobójstwo, które wyraziło się nie tylko w natychmiastowej zagładzie inteligencji zamieszkującej Stambuł, lecz przede wszystkim w przymusowych deportacjach Ormian z Anatolii do Syrii i Mezopotamii. Rozmiar tragedii potęgowała śmierć z głodu i wyczerpania prawie pół miliona ludzi wypędzonych na Pustynię Syryjską. Wielu zostało utopionych, zepchniętych w górskich przepaściach czy też spalonych żywcem lub zakopanych żywcem w ziemi. Jak podają historycy, populacja Ormian zmniejszyła się wówczas z 2,5 miliona do niespełna miliona ${ }^{43}$.

Obecnie muzułmanie, porównując to, co dzieje się na Bliskim Wschodzie od czasu tzw. arabskiej wiosny, próbują w pewien sposób wytłumaczyć to, co się stało podczas eksterminacji Ormian na początku xx wieku. Twierdzą

${ }^{42}$ G. Kucharczyk, Pierwszy holokaust..., s. 127-130.

${ }^{43} \mathrm{http} / / /$ www.ordynariat.ormianie.pl/(13.05.2015). 
często, że ludobójstwo dokonane na Ormianach nie było aktem dżihadu, gdyż jak twierdzi np. muzułmański, egipski teolog, Muhhamad Ali: „obowiązek dżihadu w islamie jest przeważnie źle rozumiany, ponieważ panuje przekonanie, że dżihad jest synonimem wojny..."44. Bez względu jednak na sposób nazwania tych wydarzeń, faktem pozostaje to, że zginęło wielu Ormian zarówno katolickich -z Katolickiego Kościoła obrządku ormiańskiego, jak i ortodoksyjnych - z Apostolskiego Kościoła Ormiańskiego.

W związku z tamtymi wydarzeniami, które dokonały się na początku xx wieku, w 2015 roku Ormianie wspominali setną rocznicę ludobójstwa. Dlatego też 12 kwietnia 2015 roku papież Franciszek odprawił mszę świętą w bazylice św. Piotra w Watykanie dla katolików obrządku ormiańskiego. Współcelebransami byli ormiańskokatolicki patriarcha Nerses Bedros XIX Tarmouni oraz biskupi i księża obrządku ormiańskiego. W trakcie mszy świętej papież Franciszek ogłosił doktorem Kościoła Grzegorza z Nareku ${ }^{45}$. Z kolei nieco wcześniej, bo w 2013 roku papież podczas spotkania z Nersesem Bedrosem xıx określił masakry Ormian jako „pierwsze ludobójstwo w historii”. Niejako zwieńczeniem tego zaangażowania ekumenicznego była papieska wizyta w Armenii w dniach 24-26 czerwca 2016 roku pod hasłem Wizyta w pierwszym kraju chrześcijańskim.

\section{Czasy współczesne wyzwaniem dla jedności Ormian}

Pewnym problemem na drodze do jedności pozostaje podział władzy duchowej w Apostolskim Kościele Ormiańskim. Pomimo iż katolikos w Eczmiadzynie sprawuje duchowe przywództwo nad tym Kościołem, to jednak na przestrzeni wieków wyłoniły się także trzy inne jurysdykcje w tym Kościele (Liban, Jerozolima, Konstantynopol). Katolikos reprezentuje wszystkich Ormian na świecie. A obecnie znajdują się oni w różnych miejscach i z różną liczebnością. Patriarchat Jerozolimy, który ma siedzibę w klasztorze św. Jakuba w tym mieście, liczy około 10 tys. wiernych. Patriarchat Konstantynopola, który na początku xx wieku obejmował około 1,9 mln wiernych, obecnie liczy zaledwie około 7o tys. wiernych. Trzecim ośrodkiem jest

${ }^{44}$ E. Machut-Mendecka, Archetypy islamu, Warszawa 2005, s. 128.

45 Był to ormiański mnich, który urodził się w 950 roku, a zmarł w 1050 roku. Pozostawił po sobie wiele znakomitych utworów, w tym najsłynniejsze swoje dzieło Księgę pieśni żałobnych. Już Jan Paweł II określił go mianem jednego z największych piewców Madonny. 
katolikat Cylicji z siedzibą w Libanie, obejmujący około 8oo tys. wiernych. Dla zapewnienia duszpasterstwa tym wszystkim wiernym Apostolski Kościół Ormiański posiada obecnie pięć seminariów. I choć wszystkie te ośrodki działają w ramach Apostolskiego Kościoła Ormiańskiego, to nie ma pomiędzy nimi pełnej jedności, której wyrazem byłoby pełne i rzeczywiste uznanie władzy tylko jednego patriarchy nad wszystkim Ormianami ortodoksyjnymi.

Duże odległości geograficzne pomiędzy wspomnianymi ośrodkami powodują niestety, że każdy z nich ma często swoje własne problemy, które nie dotyczą pozostałych. Przykładem mogą być kłopoty patriarchy w Eczmiadzynie. Po rozpadzie Związku Radzieckiego doszło do konfliktu zbrojnego, w którym uczestniczyła Armenia. Istniało prawdopodobieństwo podsycane przez wiele mediów, że miał on podłoże religijne, jako konflikt chrześcijańsko-muzułmański. W tej sytuacji w lutym 1993 roku katolikos Wasken i przełożony wspólnoty muzułmańskiej w Azerbejdżanie złożyli oświadczenie, że to nie przyczyny religijne były powodem wojny pomiędzy Armenią a Azerbejdżanem. Był to przykład problemu dotyczącego tylko jednego ośrodka Apostolskiego Kościoła Ormiańskiego.

Pomimo że około 8o proc. Ormian mieszka poza granicami swego kraju, zachowali oni własny język, odrębność kulturową oraz religijną ${ }^{46}$. Liturgia ormiańska odzwierciedla w sobie bogatą tradycję syryjską, jerozolimską i bizantyjską, co wynika to z tego, że wpływy z Syrii i Jerozolimy były szczególnie silne, gdy tworzyła się ormiańska tradycja liturgiczna pomiędzy v a viI wiekiem. Nie brak też wielu zwyczajów łacińskich przyjętych przez Ormian w średniowieczu ${ }^{47}$. Z pewnością może to być zalążek podejmowania większych wysiłków na rzecz jedności.

Do takich działań w ramach Apostolskiego Kościoła Ormiańskiego doszło już na zjeździe kościelnym w roku 1955, gdzie na Katolikosa Wszystkich Ormian wybrano patriarchę Wazgena I, który troszczył się nie tylko o poszczególne diecezje Apostolskiego Kościoła Ormiańskiego, budując i umacniając więzy jedności pomiędzy nimi, ale nadto otworzył jeszcze bardziej ten Kościół na dialog ekumeniczny poprzez wprowadzenie go do Światowej Rady Kościołów i Konferencji Kościołów Europejskich ${ }^{48}$.

${ }^{46}$ http://ekumenizm.wiara.pl/doc/477865.Ormianski-Kosciol-Apostolski-Kosciol-OrmianskoGregorianski (13.05.2015).

${ }^{47}$ R. Roberson, Chrześcijańskie Kościoły..., s. 36-37.

${ }^{48}$ B. Kumor, Historia Kościoła, cz. 8: Czasy współczesne 1914-1992, Lublin 1996, s. 592-595. 
Potem Sobór Watykański II poprzez dekret o Kościołach wschodnich katolickich, kierując swe słowa do m.in. ormiańskiego Kościoła katolickiego, stwierdził: „wszyscy chrześcijanie wschodni niech wiedzą i uważają to za rzecz niewątpliwą, że mogą i powinni zawsze zachować swoje prawowite obrzędy liturgiczne i swoje zasady karności, oraz że zmiany winny być wprowadzane jedynie dla właściwego i ograniczonego postępu" ${ }^{49}$. A Jan Paweł II w Ut unum sint stwierdził, że wszystkie osiągnięte do tej pory efekty ekumeniczne są niejako tylko jednym $\mathrm{z}$ etapów drogi do pełnej komunii ${ }^{50}$. Droga do pełnej jedności Apostolskiego Kościoła Ormiańskiego z Katolickim Kościołem obrządku ormiańskiego wydaje się zatem jeszcze odległa, choć nie brak z każdej strony przejawów dobrej woli. I tak od wielu już lat prowadzony jest dialog z Ormianami ortodoksyjnymi, w którym pośredniczy Rzym reprezentowany przez Kongregację ds. Kościołów Wschodnich i Kongregację Nauki i Wiary. To, co zapoczątkował II Sobór Watykański w dekrecie o ekumenizmie, podjął papież Paweł vi, który odwiedzając Ziemię Świętą w 1964 roku, spotkał się także z ormiańskim patriarchą Jerozolimy Derderianem. Z kolei w 1970 roku w Watykanie doszło do kolejnego spotkania między zwierzchnikami Kościołów - katolikosem Vaskenem i Pawłem vi. Natomiast Jan Paweł II zarówno w 1996, jak i 1999 roku spotkał się z Karekinem I. W 2001 roku spotkał się z jego następcą Karekinem II ${ }^{51}$. Również Kongregacja Nauki Wiary wypowiedziała się pozytywnie o Kościołach wschodnich, będących w pewnej jedności z Rzymem dzięki ważnie sprawowanej Eucharystii oraz sukcesji apostolskiej ${ }^{52}$. Sekretarz generalny Światowej Rady Kościołów ks. dr Samuel Kobia przyznał, że interkomunia pomiędzy wszystkimi wyznaniami chrześcijańskimi powinna stać się faktem do połowy obecnego wieku, wyrażając przekonanie, że Kościoły na całym świecie osiągną taką jedność, a ich wierni będą mogli się wspólnie modlić oraz wspólnie przystępować do Stołu Pańskiego. Z kolei Przewodniczący Papieskiej Rady ds. Jedności Chrześcijan stwierdził, że Kościoły chrześcijańskie powinny skupić się w dużej mierze na tym, aby częściej zajmować wspólne stanowisko w ważnych kwestiach społecznych ${ }^{53}$.

${ }^{49}$ Sobór Watykański II, dekret Orientalium Ecclesiarum, 6.

${ }^{50}$ Jan Paweł II, enc. Ut unum sint, 77.

${ }^{51}$ http://www.magazyn.ekumenizm.pl/content/article/20040705134933238.htm (18.05.2015).

${ }^{52}$ Kongregacja Nauki Wiary, dekl. Dominus Iesus, 17.

${ }^{53}$ K. Karski, Kronika wydarzeń ekumenicznych styczeń-czerwiec 2008, w: Studia i dokumenty ekumeniczne, red. K. Karski, Warszawa 2008, s. 162-164. 
Warte zaznaczenia wydaje się wydarzenie, które miało miejsce w 1997 roku w austriackim Grazu podczas II Europejskiego Kongresu Ekumenicznego. Gdy przemawiał katolikos Apostolskiego Kościoła Ormiańskiego, z jego oczu popłynęły łzy, kiedy prosił, aby bogate kraje Zachodu nie wysyłały więcej misjonarzy do jego ojczyzny. Stwierdził, że staje się to przyczyną pojawienia się pewnej nienawiści wśród jego rodaków ${ }^{54}$. Wynika $\mathrm{z}$ tego jasno, że choć ważnym elementem na drodze do jedności jest przyjęcie przez Apostolski Kościół Ormiański prymatu papieskiego, to jednak nie może dojść do zdominowania tego Kościoła i traktowania go przez Kościół rzymskokatolicki jako przywróconego do jedności z Rzymem Kościoła heretyckiego. Jednak jeszcze większym wyzwaniem na rzecz budowania jedności pomiędzy Katolickim Kościołem obrządku ormiańskiego i Apostolskim Kościołem Ormiańskim jest troska o jedność poszczególnych wspólnot ortodoksyjnych Kościoła ormiańskiego, rozrzuconych po świecie.

\section{Zakończenie}

Apostolski Kościół Ormiański jest niewątpliwie podzielony. Podział ten jednak wynika w dużej mierze z pewnych zaszłości historycznych, choć teologicznie Kościół stanowi jedną całość. W pełnej łączności z Rzymem pozostaje tylko Katolicki Kościół obrządku ormiańskiego, który wypracowywał tę jedność na przestrzeni wieków. Losy tej jedności i dalsze wyzwania dla niej zostały krótko ukazane w niniejszym artykule, począwszy od przedstawienia kształtowania się Armenii i początków Kościoła Ormian. Następnie omówione zostały podziały w ramach Apostolskiego Kościoła Ormiańskiego. Kolejny punkt ukazał wyodrębnienie się katolików ormiańskich. Konieczne było także podjęcie zagadnień związanych z prześladowaniami Kościołów Ormian. Ostatnia część pracy ukazała obecną sytuację wśród chrześcijańskich Ormian oraz podejmowane działania ekumeniczne.

${ }^{54} \mathrm{http} / / /$ www.magazyn.ekumenizm.pl/content/article/20040705134933238.htm (18.05.2015). 


\section{Bibliografia}

Bukowski K., Religie świata wobec chrześcijaństwa, Kraków 1999.

Curanowić A., Religie, Kościoły i konflikty międzywyznaniowe w regionie Kauka$z u$, w: Wprowadzenie do studiów wschodnioeuropejskich, red. M. Korzeniowski, D. Tarasiuk, K. Latawiec, Lublin 2013, s. 189-226.

Gstrein H., Skazany na chłostę i śmierć, przeł. J. Borowiczowa, Warszawa 1991. http://ekumenizm.wiara.pl/doc/477865.Ormianski-Kosciol-Apostolski-Kosciol-OrmianskoGregorianski (13.05.2015).

http://www.magazyn.ekumenizm.pl/content/article/20040705134933238.htm (18.05.2015) http://www.ordynariat.ormianie.pl/(13.05.2015).Jan Paweł II, Encyklika Ut unum sint. Karski K., Kronika wydarzeń ekumenicznych styczeń-czerwiec 20o8, w: Studia i dokumenty ekumeniczne, red. K. Karski, Warszawa 2008, s. 162-164.

Kongregacja Nauki Wiary, Deklaracja Dominus Iesus.

Kucharczyk G., Pierwszy holokaust XX wieku, Warszawa 20014.

Kumor B., Historia Kościoła, cz. 8: Czasy współczesne 1914-1992, Lublin 1996.

Machut-Mendecka E., Archetypy islamu, Warszawa 2005.

Nitkiewicz K., Katolickie Kościoły wschodnie, Sandomierz 2014.

Rudnicka-Kassem D., John Paul II, Islam and the Middle East, Kraków 2012.

Roberson R., Chrześcijańskie Kościoły wschodnie, przeł. K. Bielawski, D. Mionskowska, Bydgoszcz 1998.

Simon M., Cywilizacja wczesnego chrześcijaństwa, przeł. E. Bakowska, Warszawa 1979. Siniscalco P., Starożytne Kościoły wschodnie, przeł. K. Piekarz, Kraków 2013.

Sobór Watykański II, Dekret o ekumenizmie Unitatis redintegratio.

Sobór Watykański II, Dekret o Kościołach wschodnich katolickich Orientalium Ecclesiarum.

Stopka K., Armenia Christiana, Kraków 2002.

\section{Streszczenie}

Setna rocznica eksterminacji Ormian, przypadająca w roku 2015, obudziła większe zainteresowanie nie tylko Armenią i Ormianami, ale także historią Kościoła ormiańskiego. Artykuł kreśli zatem krótko uwarunkowania geograficzne i historyczne Armenii, aby ukazać państwo, które jako pierwsze w historii przyjęło wiarę chrześcijańską za obowiązującą. W ciągu wieków dochodziło do podziałów wewnątrz tego 
Kościoła z powodu różnic teologicznych oraz ze względów geograficznych. Tak oto powstał Apostolski Kościół Ormiański, który nie przyjął zwierzchnictwa papieża. Pomimo iż dialog Rzymu z Ormianami trwał już od XII wieku, to dopiero w XVII wieku doszło do wyodrębnienia się grupy Ormian uznających prymat papieża i do powstania Katolickiego Kościoła obrządku ormiańskiego. xx wiek przyniósł wzmożone działania ze strony Rzymu, a także ze strony kolejnych katolikosów ormiańskich, aby doszło najpierw do zjednoczenia w ramach Apostolskiego Kościoła Ormiańskiego, a następnie do pełnej jedności wszystkich Ormian z Rzymem i papieżem. Elementem wspomagającym zjednoczenie jest wspólne wspominanie ludobójstwa Ormian dokonanego przez Turków w latach 1915-1916.

\section{Słowa kluczowe}

Ormianie, Armenia, ekumenizm, Bliski Wschód

\section{Summary}

\section{Church in Armenia - divisions and striving for unity}

The hundredth anniversary of extermination of the Armenians celebrated in the year 2015 contributed to a greater interest not only to Armenia and Armenians but also to the history of the Armenian Church. This article outlines briefly geographical and historical background of Armenia in order to show complex image of the country which as the first in the history adopted the Christian faith as an official religion. Through the centuries we note many divisions inside this church because of theological differences as well as geographical reasons. As a result the Armenian Apostolic Church did not accept the supremacy of the pope. Although the dialogue with the Armenians continued from the twelfth century, it was not until the seventeenth century when a group of Armenians recognizing the primacy of the Pope established the Catholic Church of the Armenian rite. The twentieth century brought initiatives from the part of Rome as well as from the Armenians to unite the Armenian Apostolic Church and to bring all Armenians to the unity with Rome and the Pope. The element that aid the unity is the common remembrance of the Armenian genocide committed by the Turks in 1915-1916.

\section{Keywords}

Ormian, ecumenism, Middle East 